\title{
Klinik Limbah: Pengolahan Limbah Organik Berbasis 3R di Desa Kasang Pudak Kecamatan Kumpeh Ulu Kabupaten Muaro Jambi
}

\author{
Monik Kasman ${ }^{1 *}$, Venny Yusiana ${ }^{2}, \operatorname{Hadrah}^{1}$ \\ ${ }^{1}$ Program Studi Teknik Lingkungan, Fakultas Teknik, Universitas Batanghari, Jl. Slamet Riyadi, Broni, Jambi \\ ${ }^{2}$ Program Studi Teknik Listrik, Fakultas Teknik, Universitas Batanghari, Jl. Slamet Riyadi, Broni, Jambi \\ *e-mail: emka_engineer@yahoo.com
}

\begin{abstract}
ABSTRAK
Desa Kasang Pudak terletak di Kecamatan Kumpeh Ulu, berbatasan langsung dengan Kota Jambi. Kecamatan Kumpeh Ulu berkembang cukup pesat akibat meningkatnya aktivitas ekonomi dan sosial masyarakat kota sehingga turut mempengaruhi kehidupan sosial masyarakat Kota Jambi. Kurangnya kepedulian masyarakat terhadap lingkungan dan belum tersedianya layanan pengelolaan sampah serta TPA (Tempat Pemrosesan Akhir) berdampak pada kondisi lingkungan di Desa Kasang Pudak Kecamatan Kumpeh Ulu Kabupaten Muaro Jambi. Padahal produk sampingan dari aktivitas pertanian dan potensi masyarakat desa terutama ibu - ibu yang dapat diberdayakan merupakan kombinasi luar biasa dalam pengelolaan lingkungan. Oleh karena itulah, perlu adanya suatu pembinaan terhadap masyarakat untuk lebih peduli terhadap lingkungan. Program kemitraan masyarakat (PKM) ini menawarkan suatu pemberdayaan masyarakat Desa Kasang Pudak melalui pembentukan komunitas klinik limbah. Klinik limbah merupakan wadah pembinaan masyarakat yang menawarkan program-program pelatihan, pendidikan dan pemberian ketrampilan serta pendampingan terhadap warga dalam pengelolaan lingkungan terutama limbah. Mitra sasaran pengabdian ini adalah ibu-ibu yang tergabung dalam wadah kelompok peduli lingkungan Desa Kasang Pudak. Klinik limbah dalam PKM ini memberikan pelatihan dalam bentuk paparan materi dan ketrampilan meliputi pengenalan pengelolaan lingkungan, pelatihan pembuatan kompos/pupuk, pelatihan kewirausahaan dan lomba kompos. Hasil jangka panjang dari PKM adalah kemandirian ibu-ibu dan remaja putri dalam pengelolaan limbah tidak hanya meningkatkan kualitas lingkungan tapi juga pendapatan ekonomi. Kegiatan klinik limbah yang dilaksanakan mampu meningkatkan pengetahuan dan kesadaran peserta yang diindikasikan dengan kesungguhan peserta dalam pemilahan sampah dan pembuatan kompos. Hasil pemantauan sementara, penduduk berhasil memproduksi kompos dari limbah organik rumah tangga, dan digunakan untuk pupuk tanaman.
\end{abstract}

Kata kunci : Desa Kasang Pudak ; Klinik limbah; Limbah organik; $3 R$

\begin{abstract}
Kasang Pudak Village is located in Kumpeh Ulu District, directly adjacent to Jambi City. Kumpeh Ulu Subdistrict is developed quite rapidly due to the increasing economic and social activities of the urban community, which also influenced the social life of the city of Jambi. The lack of community awareness of the environment and the unavailability of waste management services and TPA (final processing facility) has an impact on environmental conditions in Kasang Pudak Village, Kumpeh Ulu District, Muaro Jambi Regency. By-products from agricultural activities and the capacity of rural community, especially women (mothers - housewives) who can be empowered, are an extraordinary combination of environmental management. Therefore, there needs to be a conjunction for the community to be more concerned on the environment. This community partnership program (PKM) offers an empowerment of the Kasang Pudak Village community through the establishment of a waste clinic community. The waste clinic is a community development forum that offers training programs, education and providing skills and assistance to residents in environmental management, especially waste. The target partners of this service are mothers - housewives who are members of the Kasang Pudak Village environmental care group. The waste clinic in this PKM provides training in the form of material exposure and skills including the introduction of environmental management, training in composting/ fertilizer making, entrepreneurship training and composting competitions. The long-term outcome of PKM is that the independence of mothers and young women in waste management not only improves the quality of the environment but also economic income. The waste clinic activities were able to increase participant's knowledge and awareness as indicated by the sincerity of participants in waste sorting and composting. As a result of the interim monitoring, residents succeeded in producing compost from household organic waste, and used it for fertilizer plants.
\end{abstract}

Kata kunci : Kasang Pudak village; Organic solidwaste; Waste clinic; $3 R$ 


\section{Pendahuluan}

Sampah adalah limbah yang bersifat padat terdiri dari zat organik dan zat anorganik yang dianggap tidak berguna lagi dan harus dikelola agar tidak membahayakan lingkungan dan melindungi investasi pembangunan. Pada umumnya paradigma masyarakat terhadap sampah dengan sifat padat yang dihasilkan dari aktivitas rumah tangga atau industri, adalah benda yang yang tidak lagi diinginkan atau tidak bernilai ekonomis (SNI, 1990). Dengan adanya UU No. 18 /2008 tentang Pengelolaan Sampah maka perlu suatu pengelolaan sampah dengan maksimal. Adapun upaya pengelolaan sampah dapat dilakukan dengan cara Reuse, Reduce, dan Recycle (3 R) adalah kegiatan memperlakukan sampah dengan cara, menggunakan kembali (Reuse), mengurangi (Reduce) dan mendaur ulang (Recycle).

Masyarakat umumnya terbiasa membuang sampah langsung ke lingkungan di sekitar rumah. Hal ini juga terjadi di Desa Kasang Pudak Kabupaten Muaro Jambi. Penduduk desa terbiasa membuang sampah langsung ke lingkungan di sepanjang desa. Belum tersedianya layanan pengelolaan sampah, Tempat Pembuangan Sementara (TPS) dan Tempat Pemprosesan Akhir (TPA) merupakan salah satu faktor pemicu kebiasaan tersebut. Masyarakat cenderung membiarkan hal tersebut tanpa mengetahui dampak negatif yang ditimbulkan di masa depan. Sampah yang menumpuk tentu akan menjadi sarang bibit penyakit, seperti diare, disentri, kolera, tifus, dan hepatitis. Secara estetika juga menimbulkan pemandangan dan bau yang tidak bersahabat.

Desa Kasang Pudak merupakan bagian dari wilayah Kecamatan Kumpeh Ulu yang berbatasan langsung dengan Kota Jambi. Kecamatan Kumpeh Ulu berkembang cukup pesat akibat meningkatnya aktivitas ekonomi dan sosial masyarakat kota sehingga turut mempengaruhi kehidupan sosial masyarakat Kota Jambi. Luas wilayah kecamatan Kumpeh Ulu adalah $820 \mathrm{~km}^{2}$ dengan penduduk 43.000 jiwa, dengan batas wilayah sebelah Utara Pusat Pemerintahan berlokasi di Desa Pudak berjarak lebih kurang $30 \mathrm{~km}$ dari Pusat Pemerintahan. Secara ekonomi kecamatan Kumpeh Ulu mempunyai nilai strategis karena merupakan supplier komoditi sayuran untuk Kota Jambi.

Kecamatan Kumpeh Ulu dikenal sebagai daerah penghasil sayur dan buah-buahan utama karena sebagian besar penduduk bermata pencarian petani, khusunya tanaman palawija dan holtikultura, hal ini didukung kondisi lahan yang sebagian terdiri dari dataran rendah/ lahan basah sehingga sangat cocok untuk budidaya tanaman sayuran dan buah-buahan. Aktivitas pertanian tersebut tentu menghasilkan dampak sampingan yaitu limbah pertanian, terutama limbah padat pertanian berupa daun, ranting, pelepah dan lainlain.

Limbah padat tersebut, mengacu pada konsep pengelolaan limbah dewasa dapat dimanfaatkan kembali menjadi produk yang bernilai. Konsep ini berupa pemanfaatan limbah kembali menjadi suatu produk lain yang bernilai komersil dan dimanfaatkan oleh masyarakat. Konsep pengelolaan limbah 3R tidak hanya mereduksi dan mencegah pencemaran akibat limbah tetapi juga meningkatkan perekonomian masyarakat. Dari pengamatan di lapangan, permasalahan mendasar ketidakpedulian masyarakat terhadap pengelolaan limbahnya adalah kurangnya pengetahuan mereka tentang limbah, dampak negatif limbah dan pengelolaan limbah yang tepat.

Potensi pemanfaatan limbah padat ini dapat meningkatkan perekonomian masyarakat setempat, terutama ibu rumah tangga. Ibu - ibu, masyarakat Desa Kasang Pudak dapat menggunakan waktu luangnya untuk hal yang lebih produktif. Disamping menambah ilmu pengetahuan mereka tentang pengelolaan limbah padat, pembinaan tersebut juga akan menambah pendapatan keluarga. Program klinik limbah yang merupakan salah satu bentuk pelaksanaan Tri Dharma Perguruan Tinggi, bertujuan memberdayakan ibu rumah tangga yang tergabung dalam komunitas peduli lingkungan untuk mengatasi permasalahan pengelolaan lingkungan.

Pemberdayaan ibu rumah tangga di desa tersebut diharapakan akan mampu memberikan kontribusi positif. Jika selama ini, masyarakat desa tidak peduli terhadap pengelolaan limbah di lingkungannya, maka dengan pembinaan komunitas pada suatu wadah yang terbentuk ini, ibu - ibu menjadi penggerak dalam pengelolaan limbah padat. lbu-ibu dan remaja putri tersebut dibina dengan memberikan pendidikan dan pelatihan tentang pemanfaatan limbah menjadi produk yang bernilai guna. Bahkan, untuk jangka panjang program ini diharapkan akan mampu menciptakan lapangan kerja baru dengan melahirkan para wiraswastawan sampah. Wadah yang akan dibentuk tersebut berupa klinik limbah yang berorientasi pada pendidikan dan pelatihan ibu rumah tangga agar mampu mengelola limbah dengan konsep 3R.

\section{Metode Pelaksanaan}

Berdasarkan analisis situasi, permasalahan yang dihadapi masyarakat Desa Kasang Pudak adalah tidak tersedianya TPS dan TPA yang layak untuk pemrosesan limbah padat dan rendahnya pengetahuan serta kepedulian masyarakat terhadap pengelolaan limbah. Maka, untuk mengatasi permasalah tersebut adalah dengan pembentukan klinik limbah. Kegiatan yang diadakan di klinik limbah meliputi:

1. Introduksi pengelolaan lingkungan.

2. Pelatihan pembuatan kompos.

\subsection{Lokasi dan Waktu Pelaksanaan}

Kegiatan pengabdian dilaksanakan di Desa Kasang Pudak, Kecamatan Kumpeh Ulu, Kabupaten Muaro Jambi. Kegiatan berlangsung pada bulan Februari hingga September 2018. Desa ini merupakan salah satu lokasi Kuliah Kerja Nyata Universitas Batanghari.

\subsection{Pelaksanaan Kegiatan}

Kegiatan pengabdian terdiri atas beberapa tahapan. 


\section{1) Pembentukan Klinik Limbah}

Klinik limbah merupakan suatu wadah komunitas peduli lingkungan, sebagai tempat pelatihan dan pembinaan masyarakat dalam mengelola limbah dengan konsep 3R. Klinik limbah yang dibentuk dikelola secara swadaya oleh ibu ibu peserta kegiatan ini. Klinik limbah ini diharapkan akan menjadi wadah yang menjembatani pembinaan masyarakat setempat secara berkesinambungan dengan pihak Perguruan Tinggi dan pakar terkait dalam pengelolaan limbah.

\section{2) Pelatihan pengelolaan limbah}

Materi yang diberikan disesuaikan dengan solusi yang ditawarkan meliputi pengelolaan lingkungan, pembuatan kompos/pupuk dan kewirausahaan. Pemberian materi ditindaklanjuti dengan praktek langsung berupa pelatihan kompos dankewirausahaan. Pengayaan materi dapat dilakukan jika komunitas klinik limbah

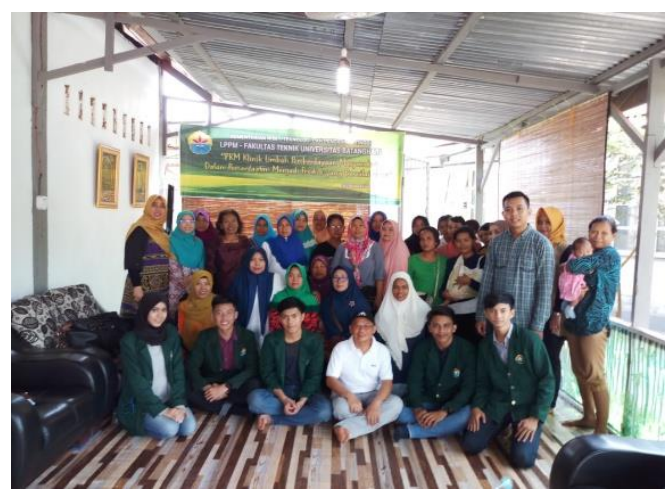

a

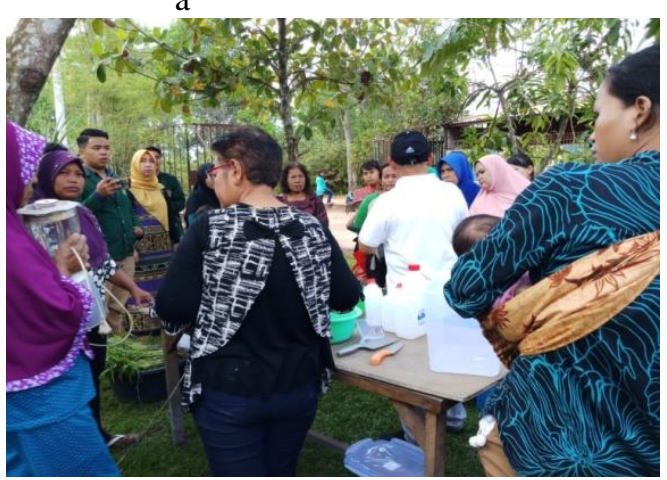

c menginginkannya. Secara teknis pelatihan akan diberikan dalam bentuk ceramah, diskusi dan praktek. Peserta yang terdiri dari komunitas klinik limbah dibentuk perkelompok untuk memudahkan monitoring dan evaluasi.

Pelatihan akan dipandu oleh 1 dosen tim pengusul pengabdian dan 1 instruktur pakar yang berpengalaman. Instruktur pakar berasal dari PT. Duta Pudak Lestari yang bergerak dalam kegiatan pengelolaan limbah yang ada di Kota Jambi. Satu materi pelatihan dilakuan dalam sehari, termasuk praktek. Peserta dibagi atas 4 kelompok, tiap kelompok mendapat satu alat komposter untuk pembuatan kompos. Dari proses pengomposan tersebut didapatkan pupuk cair dan pupuk padat. Para peserta juga diberi tugas untuk mengevaluasi keterserapan materi baik secara individu ataupun kelompok. Evaluasi dilakukan pada saat pelatihan dan tiap minggu setelah pemberian materi, selama 2 bulan melalui lembar kontrol.
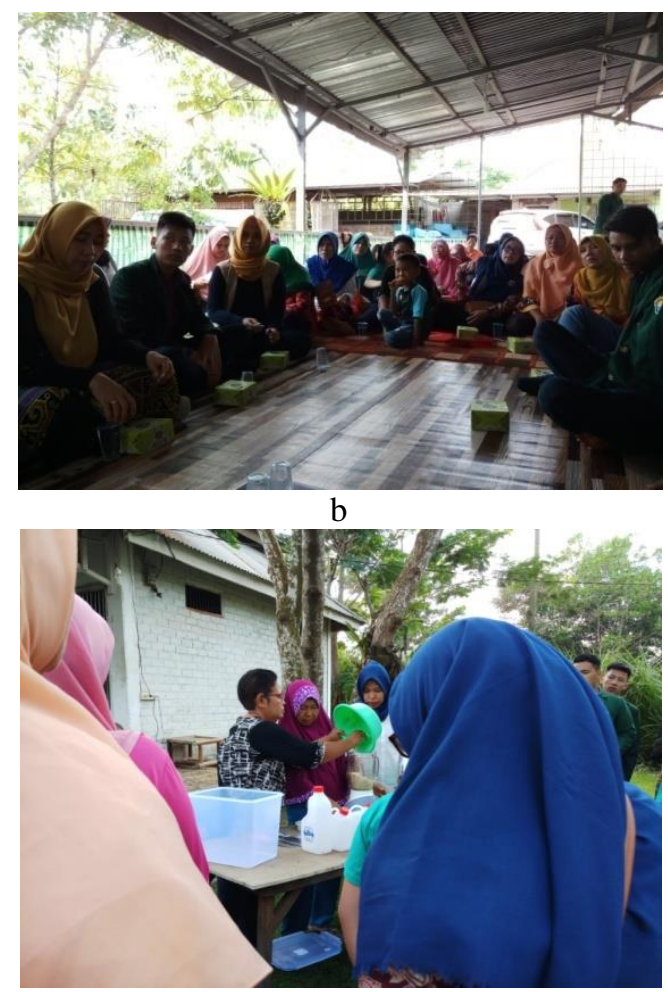

d

Gambar 1. Klinik limbah (a) Foto bersama dengan peserta. (b) Peserta mendengar penyuluhan dengan seksama (c) dan (d) Praktek pembuatan kompos 


\section{3) Monitoring dan evaluasi}

Monitoring dilakukan setelah pelaksanaan pelatihan dilakukan terhadap ibu - ibu rumah tangga. Keberhasilan program mengacu pada indikator yang telah ditetapkan. Indikator keberhasilan yang ingin dicapai:

a. Ibu-ibu peserta pelatihan meningkat kepedulian terhadap lingkungan, ini diindikasikan dengan peserta berhenti membuang sampah sembarang, mulai memilai sampah dan memasukkan sampah organik ke dalam komposter.

b. Ibu-ibu peserta pelatihan dapat menularkan pengetahuannya secara tidak langsung pada keluarga dan orang-orang terdekatnya, hingga mereka pun peduli pada lingkungan.

c. Ibu-ibu peserta terampil membuat dan menghasilkan kompos/pupuk. Ibu-ibu dan remaja putri yang tergabung dalam klinik limbah berinisiatif membuat kompos secara mandiri, menggunakannya untuk pupuk tanaman.

Evaluasi pelaksanaan kegiatan dilakukan di akhir kegiatan dengan membandingkan antara target dengan capaian. Jika terdapat kekurangan - kekurangan Pada pelaksanaan maka akan di tindaklanjuti dengan membuat dan meningkatkan kegiatan. Harapan dari program ini adalah kemandirian ibu - ibu dalam pengelolaan limbah.

\section{Hasil dan Pembahasan}

Pelaksanaan kegiatan pengabdian kepada masyarakat PKM Klinik Limbah Desa Kasang Pudak Kecamatan Kumpeh Ulu Kabupaten Muaro Jambi yang melibatkan dua kelompok peduli lingkungan yang terdiri atas ibu - ibu rumah tangga warga RT 03, RT 10, RT 29, RT 07, RT 20 dan RT 42 telah pada tahap pelaksanaan 70\% di bulan Agustus 2018. Kegiatan yang masih berjalan adalah monitoring hasil pelatihan kompos, dan kegiatan selanjutnya adalah lomba kompos sebagai puncak dan akhir kegiatan PKM Klinik Limbah tahun anggaran 2017/2018.

\subsection{Koordinasi Kegiatan}

Keberhasilan pelaksanaan PKM didukung oleh prosedur birokrasi yang dilakukan oleh tim pelaksana PKM dari Fakultas Teknik Universitas Batanghari, Jambi. Perencanaan program PKM meliputi koordinasi, pelaksanaan dan evaluasi. Koordinasi awal dilakukan pada tim inti PKM Klinik Limbah yang terdiri atas ketua tim, anggota tim dan mahasiswa yang diikutsertakan. Tujuan dari koordinasi tim inti adalah membeberkan langkah - langkah kegiatan, permasalahan yang akan dihadapi serta bagaiman mengatasinya.

Koordinasi selanjutnya berkaitan dengan pengurusan hal - hal administrasi ke pihak pemerintah terkait di lokasi pengabdian, yaitu yaitu Kepala Desa Kasang Pudak dan Ketua RT, serta ibu-ibu rumah tangga Desa Kasang Pudak dalam wadah Kelompok Peduli Lingkungan. Tujuan dari koordinasi untuk menyepakati pembentukan klinik limbah dan jadwal kegiatan pelatihan. Kegiatan klinik limbah bekerjasama dengan pihak PT. Duta Pudak Lestari yang berada di RT 03 Desa Kasang Pudak. Pihak PT. Duta Pudak Lestari berpartisipasi sebagai narasumber praktisi dan koordinator kelompok peduli lingkungan. Oleh karena itu, koordinasi terakhir dilakukan dengan pihak PT. Duta Pudak Lestari. Pelaksanaan kegiatan diawali dengan pembentukan kelompok pengelola klinik limbah. Kegiatan dilakukan di balai PT. Duta Pudak Lestari, yang akan mengkoordinasi langsung kelompok peduli lingkungan dan pelaksanaan pelatihan. Hal ini dilakukan untuk memudahkan pelaksanaan dan monitoring kegiatan. Evaluasi kegiatan dilakukan melalui observasi langsung pada peserta dan monitoring terhadap proses pengomposan dan hasil yang didapatkan. Evaluasi dilakukan terhadap kelompok dan individu.

\subsection{Pelaksanaan Kegiatan}

Berdasarkan permasalahan yang dihadapi masyarakat di Desa Kasang Pudak, maka bentuk kegiatan yang dilakukan adalah transfer ilmu pengetahuan dan teknologi berupa penyuluhan dan pelatihan. Fokus kegiatan klinik limbah pada tahun anggaran 2017/2018 adalah pelatihan pembuatan dan pemanfaatan kompos dan limbah organik. Pada kegiatan ini, peserta terdiri atas ibu - ibu rumah tangga dari beberapa RT di Desa Kasang Pudak. Peserta berasal dari dua wadah Kelompok Peduli Lingkungan, sebanyak 24 orang. Pada kegiatan pelatihan, peserta dibagi menjadi empat kelompok, dimana tiap kelompok terdiri atas 6 orang. Tiap kelompok mendapat satu unit komposter sebagai alat pembuat kompos. Hasil dari proses pengomposan berupa pupuk padat dan pupuk cair yang dapat digunakan langsung oleh anggota kelompok pada tanaman mereka.

\subsection{Pembentukan klinik limbah}

Klinik limbah yang dibentuk pada tahap ini, berupa bakal pusat pelatihan dan pembinaan pengolahan limbah 3R. Lokasi dan koordinasi kegiatan klinik limbah dilakukan di Balai latihan PT. Duta Pudak Lestari.

\subsection{Pelatihan pembuatan kompos dan kewirausahaan}

Pelatihan dilakukan dua kali, dimana satu kali pelatihan dilakukan dari jam 8 pagi hingga jam 4 sore. Pelatihan dilakukan di Balai PT. Duta Pudak Lestari. Materi diberikan oleh dosen dari tim inti pengabdian dan praktisi dari PT. Duta Pudak Lestari. Materi yang diberikan berupa pengetahuan dasar tentang pengelolaan lingkungan, sampah, pembuatan kompos, dan kewirausahaan. Inti dari materi adalah paparan pemanfaatan sampah rumah tangga menjadi produk bernilai guna. Pelatihan diikuti dengan praktek langsung pembuatan kompos, peserta secara aktif dan antusias mengikuti praktek. Pelatihan dan praktek diselingi dengan tanya jawab secara interaktif. Peserta diberi pemahaman tentang sampah organik dan sampah anorganik, pemilahan sampah, pewadahan, dan 
pemanfaatannya. Setelah itu, dilanjutkan dengan penjelasan kompos, teknik pengomposan, dan hasil dari pengomposan. Peserta juga diajak untuk melihat langsung tanaman organik yang telah dibudidayakan oleh pihak PT. Duta Pudak Lestari dengan memanfaatkan pupuk padat dan cair hasil pengomposan. Setelah pelatihan, kelompok peserta diberi satu unit alat komposter. Alat tersebut digunakan secara kelompok untuk mempraktekkan langsung pembuatan kompos dari sampah organik rumah tangga.

\section{1) Monitoring dan evaluasi pembuatan kompos}

Setelah pelatihan, kelompok peserta mempraktekkan langsung pembuatan kompos tersebut. Kegiatan pemantauan didampingi oleh dua orang mahasiswa untuk satu kelompok. Disamping dipantau melalui pengisian lembar kontrol, kelompok peserta juga dibimbing mengatasi permasalahan pada proses pembuatan kompos. Kegiatan ini juga merupakan tahap penilaian dan evaluasi pelatihan. Hasil yang didapat dari lembar kontrol dan pengamatan akan menentukan nilai kelompok peserta. Kegiatan monitoring dapat dilihat di gambar 2

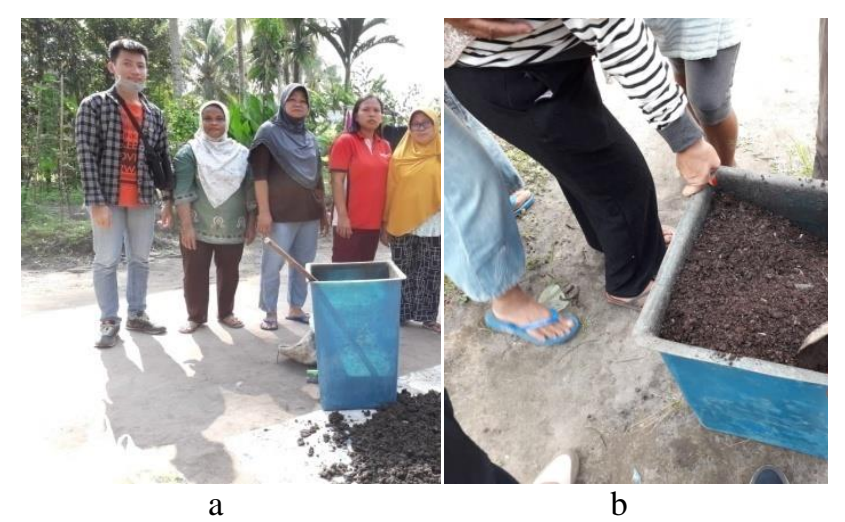

Gambar 2. (a) Monitoring terhadap masing-masing kelompok peserta klinik limbah. (b) Kompos yang dihasilkan oleh peserta klinik limbah.

Berdasarkan pelatihan dari program klinik limbah tahun anggran 2017/2018, terlihat perubahan pola pikir dan prilaku peserta pelatihan. Diantaranya:

1) Peserta pelatihan memahami perbedaan limbah padat organik dan limbah padat anorganik, dan mengetahui cara pembuatan kompos dari sa

2) Peserta pelatihan terbiasa memisahkan atau memilah limbah padat organik dan limbah padat anorganik

3) Peserta pelatihan terbiasa memasukkan limbah padat organik, sisa dapur dan limbah pertanian di alat komposter

4) Peserta pelatihan menggunakan kompos padat dan cair untuk tanaman.

\section{Kesimpulan}

Kesimpulan yang dapat diperoleh dari pelaksanaan program pengabdian kepada masyarakat PKM Klinik Limbah Desa Kasang Pudak adalah:

1) Pengetahuan dan kesadaran peserta meningkat setelah pelatihan, diindikasikan dengan kesungguhan peserta dalam pemilahan limbah padat dan pembuatan kompos.

2) Peserta mampu membuat kompos dari limbah padat organik.

\section{Ucapan Terima Kasih}

Penulis mengucapkan terima kasih pada DP2M Ristek Dikti yang telah mendanai kegiatan ini dengan skim anggaran pengabdian Program Kemitraan Masyarakat Tahun Anggaran 2017/2018. Terima kasih juga dihaturkan pada Lembaga Pengabdian kepada Masyarakat (LPPM) Universitas Batanghari, civitas akademika Fakultas Teknik Universitas Batanghari, Pihak PT. Duta Pudak Lestari dan Masyarakat Desa Kasang Pudak yang telah berpartisipasi dalam kegiatan ini.

\section{Daftar Pustaka}

BPS. (2016). Statistik Daerah Kecamatan Jambi Luar Kota. Jambi.

Metcalf \& Eddy. (2003). Wastewater Engineering Treatment and Reuse. New York: Mc.Graw Hill.

Municipal, S.C. (2010). Takakura Home Method (THM) Composting. Dipetik pada tanggal 27 September 2017, dari Sibu Municipal Council http://sdi.com.my/docs/takakura_resized.pdf.

Wahyuni, Sri. (2011). Menghasilkan Biogas dari Aneka Limbah. Jakarta: PT. Agromedia Pustaka.

Gufron, M.A., et al. (2017). Pelatihan Pengolahan Sampah Organik Menjadi Kompos Dengan Media Keranjang Takakura. J-ABDIPAMAS, 2(1), 98 - 108. 